Acknowledgment is made to the Agricultural Research Council for its support of this work, and to Messrs. May and Baker, who supplied samples of $\gamma-(2: 4$-dichlorophenoxy)butyric acid for testing.

Department of Botany, University of Glasgow. Jan 23.

${ }^{1}$ Fawcett, C. H., Ingram, J. M. A., and Wain, R. L., Nature, 170, 887 (1952); Proc. Roy. Soc., B, 142, 60 (1954). Wain, R. L., and Wightman, F. Proc. Roy. Soc., B, 142,525 (1954). Wain, R. L. l'roc. British Weed Control Conf., 2, 311 (1954). Fawcett; C. H.' Seeley, R. C., Taylor, F., Wain, R. L., and Wightman, F., Nature, 176, 1026 (1955)

\section{Effect of the Anion on RF Values of Quaternary Ammonium Salts}

THE effect of anions on the $R_{F}$ value of cations is in most cases ignored, since little interaction has ever been found to exist. Pollard et al. ${ }^{1}$ refer to the different $R_{F}$ 's of various cupric salts and also demonstrate that lead, sodium and potassium move separately from their respective anions. Lederer ${ }^{2}$ states that butanol saturated with $0.5 \mathrm{~N}$ ammonium hydroxide keeps halide salts completely in the ionic form and that they move as ions. Others ${ }^{3}$ have noted different $R_{F}$ 's with several salts of acetylcholine.

While studying the in vitro metabolism of the ganglionic blocking agent, 'Ecolid' chloride $(4,5,6,7$. tetrachloro-2-(2-dimethylaminoethyl)-isoindoline dimethochloride) ${ }^{4}$, we noticed that after precipitation of tissue proteins with trichloracetic acid, paper chromatograms of the acid solution yielded one spot with $R_{F}$ value $0 \cdot 67$, whereas 'Ecolid' chloride itself gave $R_{F} 0 \cdot 18$. If, however, 'Ecolid' was precipitated with reinecke salt and the reineckate chromatographed after treatment of the material at the origin with silver nitrate to split the salt ${ }^{6}$, a spot with $R_{F} 0 \cdot 23$ resulted. A possible explanation for these phenomena is that salts of 'Ecolid' migrate in undissociated form. Therefore, the trichloracetic acid filtrate would give a spot of 'Ecolid' trichloracetate whereas silver nitrate treatment of the reineckate would yield a spot of 'Ecolid' nitrate.

To test this hypothesis, a solution of 'Ecolid' chloride was passed through an anion exchange resin, 'Permutit S-2', and the 'Ecolid' hydroxide thus obtained was added to various salt solutions. Aliquots of these solutions were then subjected to ascending paper chromatography along with the 'Ecolid' hydroxide using two solvents. Solvent $A$ consisted of $n$-butanol saturated with $0.1 N$ ammonium hydroxide, whereas solvent $B$ consisted of 20 per cent ammonium hydroxide in 95 per cent ethanol. In all cases identification of 'Ecolid' was by spray. ing the chromatogram with a modified. Dragendorff solution ${ }^{5}$.

It is apparent from Table 1 that the nature of the anion markedly affects the $R_{F}$ of the 'Ecolid' cation. The iodide and trichloracetate salts of 'Ecolid' are relatively insoluble and crystals of each have been obtained which are homogeneous by paper chromatography. The iodide displays the same $R_{F}$ as one prepared by another route.

Shepherd and West describe the appearance of a second adrenaline-like spot in trichloracetic acid filtrates, which seems to be a complex of trichloracetic acid and adrenaline. They suggest compound formation between the weak phenolic group of adrenaline and trichloracetic acid as the cause. Simple salt formation between adrenaline cation and trichloracetic acid anion, similar to that observed
Table 1

\begin{tabular}{|c|c|c|}
\hline Anion & \multicolumn{2}{|c|}{$\underset{A^{*}}{R F}$ of 'EcolidTM' in solvents } \\
\hline $\begin{array}{l}\text { Hydroxide } \\
\text { Fluoride } \\
\text { Chloride } \\
\text { Bromide } \\
\text { Iodide } \\
\text { Carbonate } \\
\text { Nitrate } \\
\text { Acetate } \\
\text { Phosphate } \\
\text { Sulphate } \\
\text { Trichloracetate }\end{array}$ & $\begin{array}{c}0 \cdot 15-0 \cdot 16 \\
0 \cdot 18 \\
0 \cdot 18 \\
0 \cdot 24 \\
0 \cdot 25-0 \cdot 29 \\
0 \cdot 58 \\
0.23-0.24 \\
0 \cdot 56 \\
0 \cdot 61-0 \cdot 63 \\
0 \cdot 64-0.65 \\
0.65-0.69\end{array}$ & $\begin{array}{c}0 \cdot 10-0 \cdot 13 \\
0 \cdot 18-0 \cdot 19 \\
0 \cdot 45-0 \cdot 5 \\
0 \cdot 52-0 \cdot 54 \\
0 \cdot 62 \\
0 \cdot 25-0 \cdot 27 \\
0.51-0 \cdot 52 \\
0 \cdot 51 \\
0 \cdot 74 \\
=.77\end{array}$ \\
\hline
\end{tabular}

with trichloracetic acid and 'Ecolid', could easily explain the effect observed by Shepherd and West.

The effect of anions on the $R_{F}$ of cations, in this case a bisquaternary ion, emphasizes that care must be taken in the interpretation of chromatograms from natural fluids or tissue extracts. The danger of loss of material due to the formation of relatively insoluble salts was underlined by our observation of a sparingly soluble 'Ecolid' trichloracetate in trichloracetic acid filtrate preparations. Therefore, standard solutions should not be prepared with simple solvents but with the fluid or tissue extract under consideration.

Research Department,

HERBERT SHEPPARD

Barbara SACHS D'Asaro

Ciba Pharmaceutical Products, Inc.,

Summit, New Jersey. Dec. 27.

3 Pollard, F. H., McOmie, J. F. W., and Elbeih, I. I. M., J. Chem. Soc., 466 and 470 (1951).

2 Lederer, M., Science, 110, 115 (1949).

${ }^{3}$ Chefurka, W., and Smallman, B. N., Nature, 175, 946 (1955). Whittaker, V. P., and Wijesundera, S., Biochem. J., 51, 348 (1952)

4 Plummer, A. J., Trapold, J. H., Sehneider, J. A., Maxwell, R. A.; and Earl, A. E., J. Pharmacol. and Exp. Therap., 115, 172 (1955). ${ }^{5}$ Bregoff, H. M., Roberts, E., and Delwiche, C. C., J. Biol. Chem.,

- Shepherd, D. M., and West, G. B., Nature, 169, 797 (1952).

\section{Arcs in Vacuum}

DURING an investigation of the behaviour of electric arcs in vacuum, measurements have been made of are voltages with various cathode materials, and photographs have been taken of cathode spot tracks on one particular material. Certain of these measurements may be relevant to phenomena occurring at the opening of low-current contacts in air.

To enable an arc to burn in a high vacuum, one electrode at least must vaporize. In all the tests made, the cathode provided the vapour from high current-density cathode spots.

Although the arcing voltages were exceedingly ragged, the average areing voltage depended on the cathode material, as did the current necessary to maintain a stable arc. A solid cadmium cathode, for example, allowed a 2-amp. arc to burn steadily, whereas an arc with a tungsten cathode was unstable even at 50 amp. Oscillograph records showed no sign of a change of average arc voltage as an initially clean steel anode became coated with vapour from the cathode, and when cadmium was used as the cathode, heating the anode to a temperature above the boiling point of cadmium did not affect the average arcing voltage.

The anode was a flat steel disk about 2 in. in diameter, and pieces about $\frac{1}{2} \mathrm{in}$. in diameter were used for cathodes, except in the cases of gold and nickel, when wires were used. The arcs, which were 